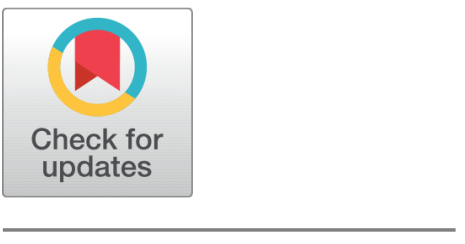

OPEN ACCESS

Received: 27.11.2020

Accepted: 27.01.2021

Published: 12.02 .2021

Citation: Achary B, Rohini S (2021) Electron micrograph studies on the effects of fluoxetine in depression-induced adult female rat ovaries. Indian Journal of Science and Technology 14(5): 406-414. http s://doi.org/10.17485/IJST/v14i5.2080

* Corresponding author.

achary.b@gmail.com

Funding: None

Competing Interests: None

Copyright: (c) 2021 Achary \& Rohini. This is an open access article distributed under the terms of the Creative Commons Attribution License, which permits unrestricted use, distribution, and reproduction in any medium, provided the original author and source are credited.

Published By Indian Society for Education and Environment (iSee)

ISSN

Print: 0974-6846

Electronic: 0974-5645

\section{Electron micrograph studies on the effects of fluoxetine in depression-induced adult female rat ovaries}

\author{
Bindu Achary ${ }^{1 *}$, Sivabalan Rohini ${ }^{2}$ \\ 1 Zoology Department, R.Jhunjhunwala College, Ghatkopar, Mumbai, 400086, India \\ 2 Zoology Department, Ruia College, Matunga, Mumbai, 400019, India
}

\section{Abstract}

Background: Fluoxetine is a common drug in the treatment of major depressive disorders. However, its effects on the ovarian tissues are less explored. The objective of this study, therefore, is to examine the ultrastructural changes in the ovaries of depressed rats undergoing treatment with fluoxetine by electron micrograph (EM) analysis. Biochemical assays will indicate the functional aspects of the ovaries. Methods/Statistical analysis: The female Wistar rats selected for the study were given doses of reserpine drug to induce depression. Following this, treatment with fluoxetine at $10 \mathrm{mg} / \mathrm{kg}$ and $20 \mathrm{mg} / \mathrm{kg}$ was given. The blood samples were collected by retro-orbital method and used for the biochemical assays. Further, the analysis of the data was done by one-way ANOVA. The animals were sacrificed, ovaries isolated and processed for electron microscopy. The EM was observed and interpreted. Findings: EM studies on the ovarian tissues of depression-induced female rats undergoing treatment with $20 \mathrm{mg} / \mathrm{kg}$ fluoxetine show the presence of an inconspicuous nucleus, several hydrated mitochondria, glycogen granules, fibroid encompassing the ovarian follicle and heavy invasion of stereo cilia. The biochemical assays also indicate a highly significant decrease in the ovarian hormones in this group at $\mathrm{P}=0.05(5 \%)$. Applications: The results are indicative of the detrimental effects of fluoxetine at $20 \mathrm{mg} / \mathrm{kg}$ on the rat ovaries. Fluoxetine therapy for the treatment of depression in females should be in consideration with its influence on ovaries and ovarian hormones.

Keywords: Fluoxetine; electron micrographs; rat ovary

\section{Introduction}

Fluoxetine, approved for the treatment of depression, is a highly effective Selective Serotonin Reuptake Inhibitor (SSRI) in vitro and in vivo ${ }^{(1)}$. In clinical trials of antidepressants, the placebo effects with fluoxetine were found to be high in the range of $30 \%$ for subjects diagnosed with major depression ${ }^{(2)}$. In addition to the less aversive side effects and comparable efficacy, SSRIs in particular fluoxetine, has a wider therapeutic index ${ }^{(3-6)}$. The most benefits from fluoxetine tend to occur in people who have moderately severe illness ${ }^{(5)}$. 
Fluoxetine is beneficial in the treatment of depression, however, its effects on the female ovaries is to be clearly understood. It is observed that in rats, fluoxetine and norfluoxetine cross the placenta and distribute within the foetus during the periods of organogenesis and post organogenesis ${ }^{(7)}$. Fluoxetine at high concentrations were found to inhibit the contraction induced by potassium ion on the isolated rat uterus preparation ${ }^{(8)}$. Other studies reveal that there is a reduced libido in adult rats chronically exposed to fluoxetine ${ }^{(9)}$. Fluoxetine was also found to reduce the aggressive behavior displayed during the diestrus phase by normally cycling rats ${ }^{(10)}$. In addition to these behavioral and physiological responses to fluoxetine treatment, histological alterations in the reproductive organs are a possibility. Studies on the histological changes in rat ovaries in response to several chemicals were done using light and electron microscopy ${ }^{(11-15)}$. However, EM studies on ultrastructural changes of ovaries of depressed rats undergoing treatment with fluoxetine have not been worked out so far.

The ultrastructural changes in turn may affect the secretion of ovarian hormones. Research findings indicate that females and males use different hormonal and neural mechanisms to respond to the same emotional event ${ }^{(16)}$. The critical role of ovarian hormones in the behavioral, inflammatory and cardiovascular susceptibility to social stress in female rats has been noted ${ }^{(17)}$. It is also observed that the estrogen can pass the brain-blood barrier and bind to cytoplasm estrogen receptor (ER)- $\alpha$ and ER- $\beta$ in different areas of the limbic system of the brain. During conditions of stress, estrogen can thus modulate the behavioral and neurobiological response depending on the concentrations of estrogen ${ }^{(18)}$. Estrogen replacement retrieved OVX (ovariectomy)induced nociceptive hypersensitivity and depressive-like behaviors ${ }^{(19)}$. Estrogen $\mathrm{E}_{2}$ and DHT (dihydrotestosterone) have some anti-depressant effects but the modest PNS (prenatal stress) may alter $\mathrm{E}_{2}$ 's ability to alleviate some depressive behavior in female and not male rats ${ }^{(2)}$. These studies suggest that levels of estrogen and progesterone play an important role in major depressive disorders.

The current study investigates the dose effects of fluoxetine at $10 \mathrm{mg} / \mathrm{kg}$ and $20 \mathrm{mg} / \mathrm{kg}$ on the ultra-structure of ovaries and ovarian hormones in depression-induced female rats.

\section{Materials and Methods}

\subsection{Animal treatment}

Animal models of depression include the Flinders Sensitive Line (FSL) rat, the Wistar Kyoto (WKY) rat, the Fawn-Hooded (FH) rat and the Learned Helpless (LH) rat ${ }^{(21)}$. Female Wistar rats weighing between $100-150 \mathrm{~kg}$ initially (i.e., before leading them to develop depression clinically) were selected. The animals were obtained from Bharat Serum and Vaccines Ltd., Thane and were housed in the Animal House, R. Jhunjhunwala College, Ghatkopar, CPCSEA registration number 525/02/.a. The animals were acclimatized in the laboratory for about a week and were treated and cared for in accordance with Organization for Economic and Community Development (OECD) guidelines.

The animals were housed individually in polyurethane cages with wire mesh tops and rice husk bedding which was changed every day. The temperature in the experimental animal room was maintained at $22^{\circ} \mathrm{C}\left( \pm 3^{\circ} \mathrm{C}\right)$. The humidity was around 50$60 \%$. Artificial lighting with a sequence of 12 hours light and 12 hours dark was maintained. For feeding, conventional rodent laboratory diets were used and water was provided ad-libitum in bottles. Commercially available rat feed was supplied by 'Amrut' laboratory animal feed.

\subsubsection{Experimental design}

The female Wistar rats were sorted into four groups of 5 each. The drugs under study were dissolved in distilled water and all doses were given intraperitoneally in morning hours. Reserpine puriss (LOBA Chemicals) was injected for inducing depression ${ }^{(22-26)}$. Fluoxetine (Prozac) was used as an antidepressant for treatment.

\section{a) Animal grouping and dosage}

Group I (Control): Sterile distilled water $2 \mathrm{cc} / \mathrm{kg}$ was administered for 21 successive days.

Group II (Depression induced): Sterile distilled water $2 \mathrm{cc} / \mathrm{kg}$ was administered for 21 successive days. Reserpine dose of $3 \mathrm{mg} / \mathrm{kg}$ body weight was given for 7 successive days.

Group III (Depression induced + Treated): Reserpine $3 \mathrm{mg} / \mathrm{kg}$ body weight was given for 7 successive days. Fluoxetine (10 $\mathrm{mg} / \mathrm{kg}$ body weight) was administered for 21 successive days.

Group IV (Depression induced + Treated): Reserpine $3 \mathrm{mg} / \mathrm{kg}$ body weight was given for 7 successive days. Fluoxetine (20 $\mathrm{mg} / \mathrm{kg}$ body weight) was administered for 21 successive days.

b) Sample collection

At the end of each treatment blood samples were collected by retro-orbital method for biochemical assays. Animals were sacrificed after ether anesthesia by cervical dislocation, dissected, examined for any visible alterations in anatomy. Ovaries were 
quickly removed and processed for Electron microscopy.

c) Biochemical assays

Serum estradiol and progesterone hormone was detected by radioimmunoassay.

d) Electron microscopy

Processing of tissue was done for routine electron microscopy. Fixation was done with $1 \%$ osmium tetrasulphate in sodium cacodylate buffer, followed by alcoholic degradation. Embedding of tissue blocks were done in BEEM capsules with fresh araldite 'B' solution. Ultrathin sections or 'thin sections' 600-900 $\mathrm{A}^{0}$ were cut on a Leica ultra cutter R, with glass knives, prepared on a Leica (knife make) EMKMR2. Sections were collected on 300 mesh copper grids and observed on JEOL-1010 electron microscope.

\section{Results and Discussions}

\subsection{Biochemical assays}

Data obtained from experimental studies with each independent variable in four groups were analysed by One-way Analysis of Variance (ANOVA). The results obtained were statistically significant at $\mathrm{P}=0.05$ (5\%) (Table 1).

Table 1. Biochemical parameters analysed in different groups

\begin{tabular}{lllll}
\hline Parameters & Group I & Group II & Group III & Group IV \\
\hline Estradiol ng/ml (Serum) & $34.0 \pm 0.55$ & $19.12 \pm 0.08$ & $29.1 \pm 0.07$ & $16.12 \pm 0.08$ \\
Progesterone $\mathrm{ng} / \mathrm{ml}$ (Serum) & $24.1 \pm 0.07$ & $21.06 \pm 0.05$ & $22.14 \pm 0.08$ & $9.08 \pm 0.08$ \\
\hline
\end{tabular}

\subsection{Electron Micrograph (EM) studies}

Group I: EM of rat ovary of control shows distinct irregularly shaped Nucleus (N). Intact mitochondria (M) with distinct cristae and dense matrix are visible. Some of the degenerating mitochondria (DM) are also observed (Figure 1). There is the presence of autophagic vacuole (AV) and Golgi bodies (G).

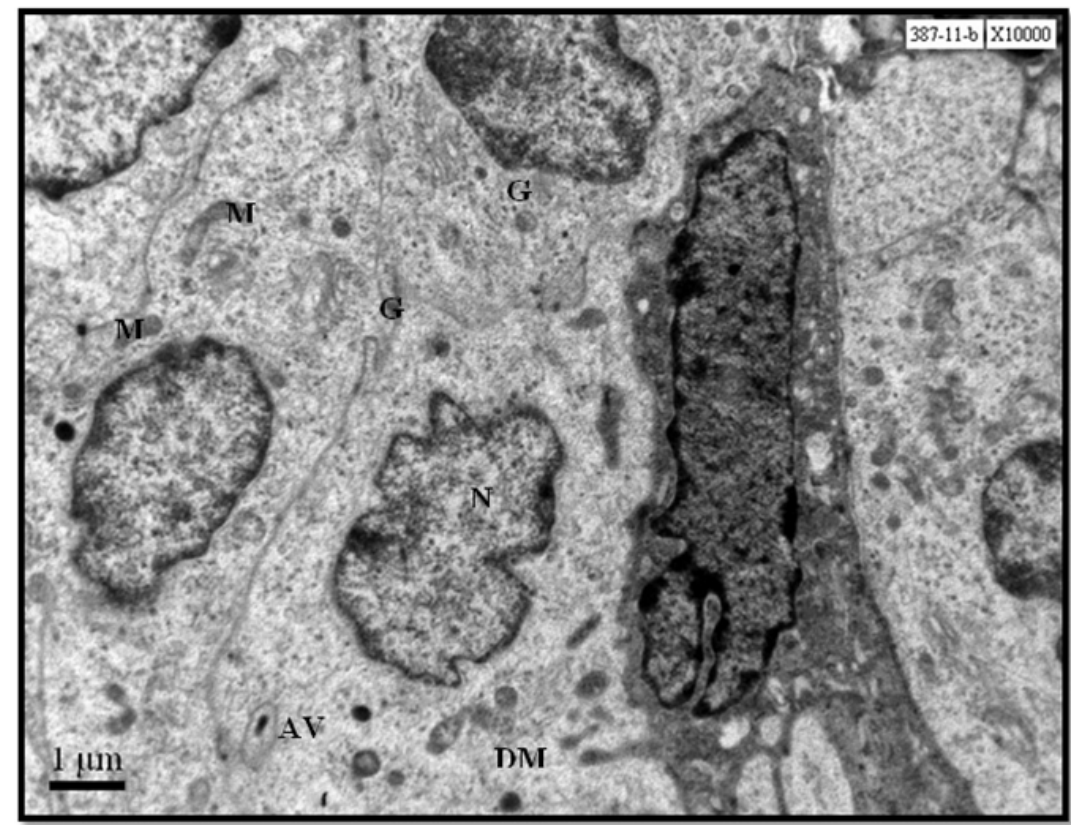

Fig 1. EM of rat ovary of control exhibiting distinct irregularly shaped Nucleus $(\mathrm{N})$

Group I: EM of rat ovary of control shows distinct Graafian follicle (GF) and ovarian follicle (F) under developmental stages (Figure 2). Also, note the peripheral stromal cells (S). 


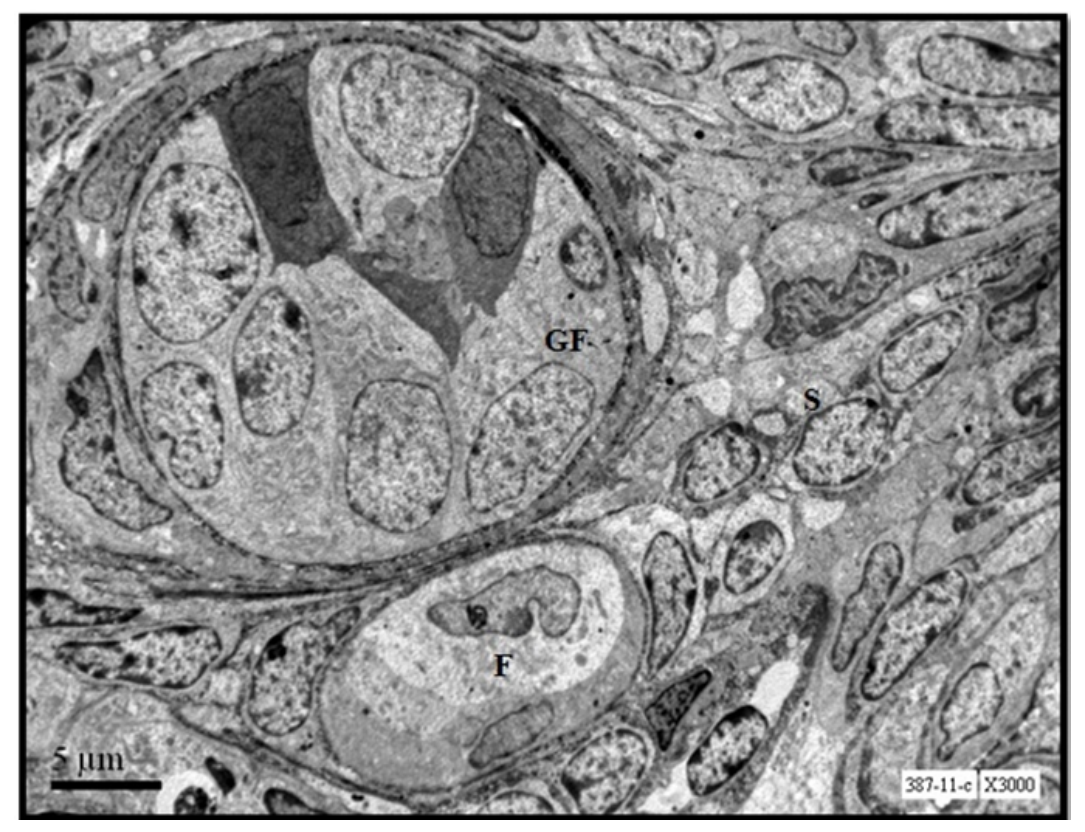

Fig 2. EM of rat ovary of control exhibiting distinct Graafian follicle (GF) and ovarian follicle (F) under developmental stages

Group II: EM of rat ovary treated with reserpine shows distinct nucleus $(\mathrm{N})$ with the nucleolus $(\mathrm{Nu})$. Note the polyribosome chains in the ovum (P). Several free ribosomes and polyribosomes give a granulated appearance to the cytoplasm (Figure 3). A stray appearance of crystalloids $(\mathrm{C})$ is noticed. Ovum is with a thick membrane (M).

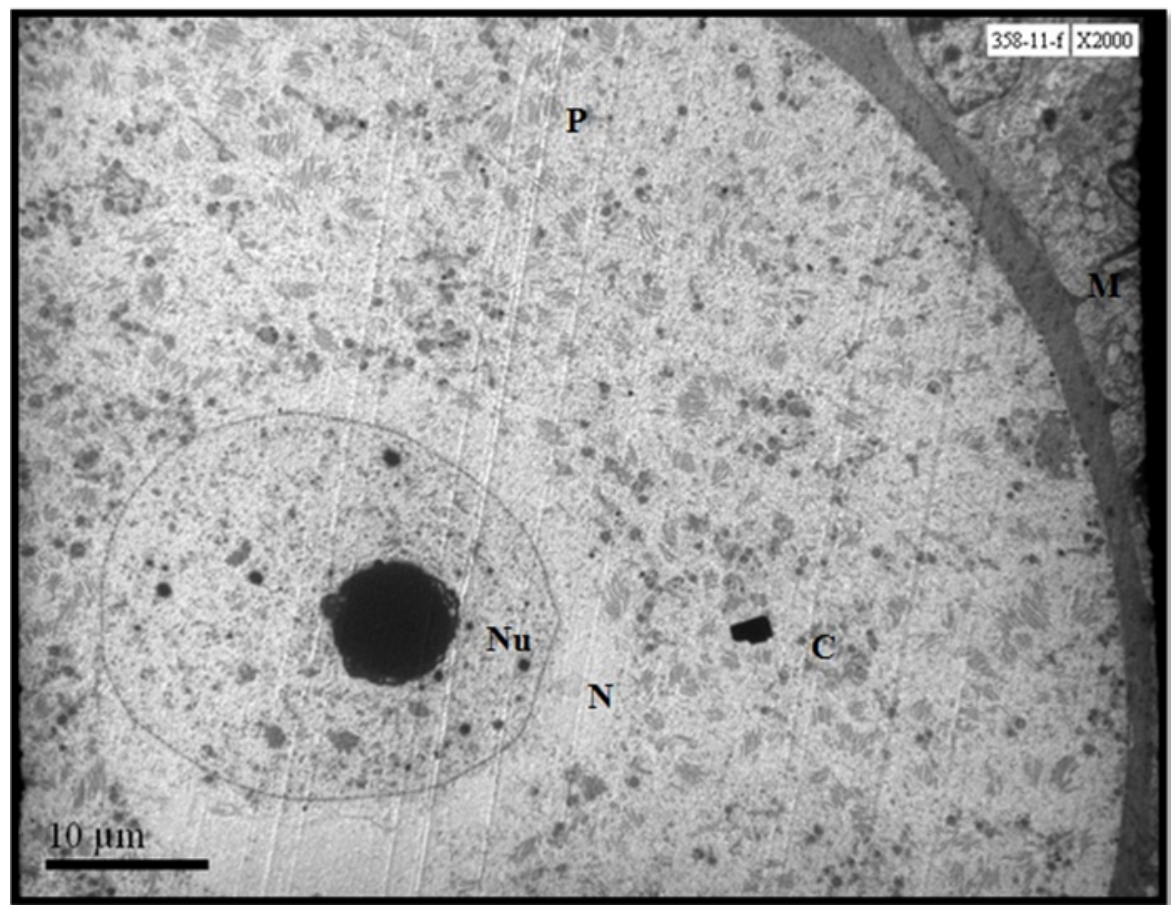

Fig 3. EM of rat ovary treated with reserpine shows distinct nucleus $(\mathrm{N})$ with the nucleolus $(\mathrm{Nu})$.

Group II: EM of rat ovary treated with reserpine shows Graafian follicle with distinct nuclei $(\mathrm{N})$. The number of mitochondria (M) is more indicating a higher synthesis of ATP. Vacuole (V) and primary lysosomes (Ly) are seen (Figure 4). 
Note the presence of a dense body $(\rightarrow)$.

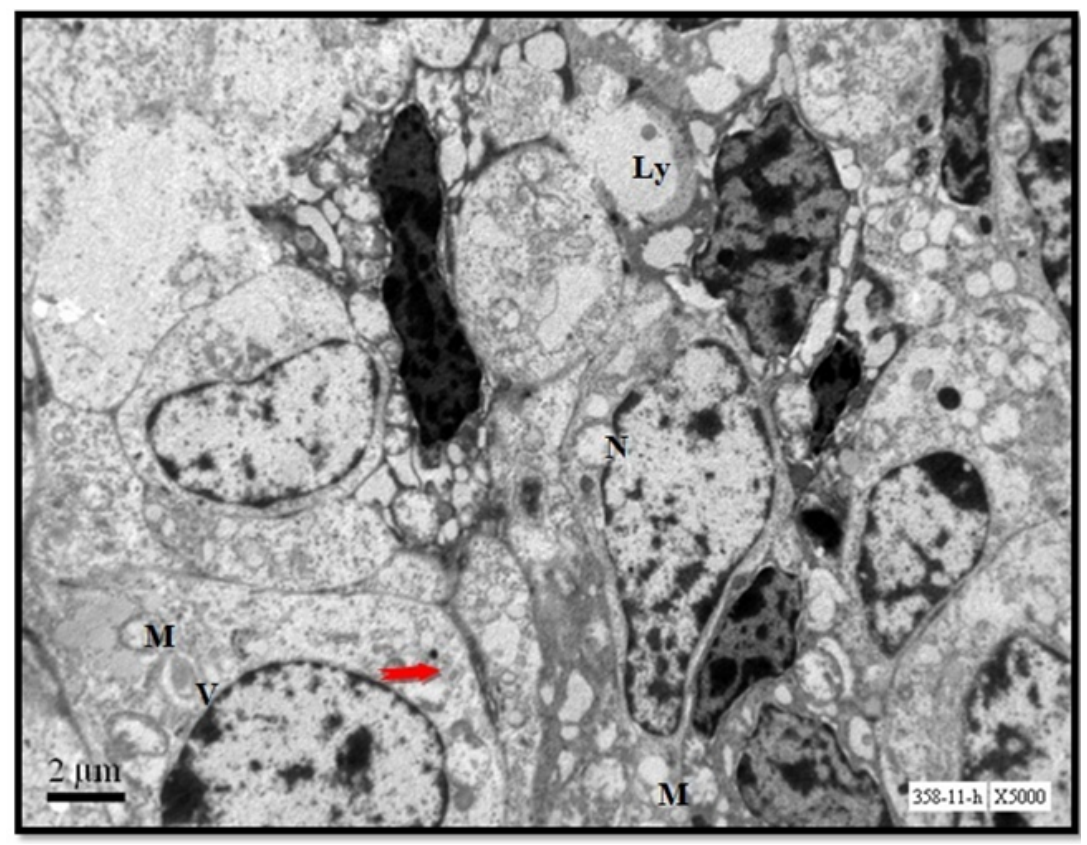

Fig 4. EM of rat ovarytreated with reserpine exhibiting Graafian follicle with distinct nuclei (N)

Group III: EM of rat ovary treated with fluoxetine $10 \mathrm{mg} / \mathrm{kg}$ shows secretory granules (SG) which are polymorphic. Note the primary ovarian follicle undergoing degeneration (F). Several hydrated mitochondria (M) with loss of cristae are also observed (Figure 5).

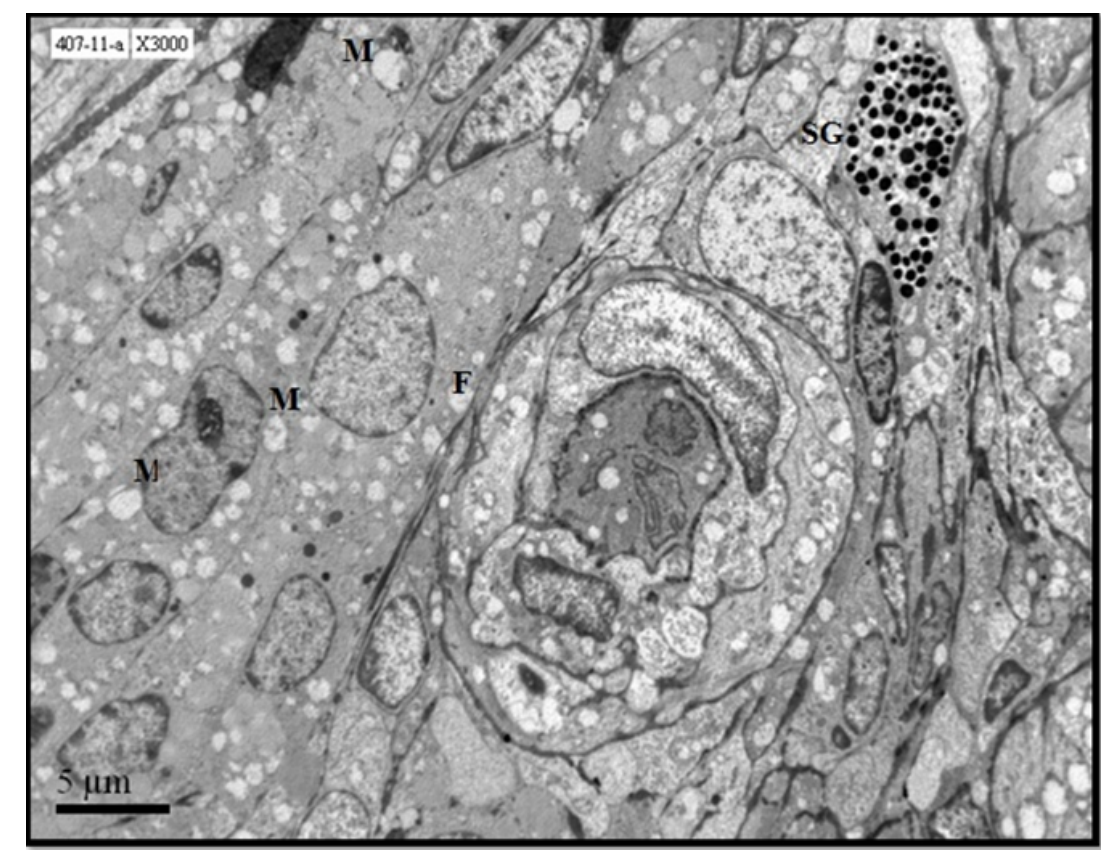

Fig 5. EM of rat ovary treated with fluoxetine $10 \mathrm{mg} / \mathrm{kg}$ exhibiting secretary granules (SG)

Group III: EM of rat ovary treated with fluoxetine $10 \mathrm{mg} / \mathrm{kg}$ with distinct mitochondria $(\mathrm{M})$ and nucleus $(\mathrm{N})$. Note the presence of Juxta nuclear Golgi region $(\mathrm{G})$ in the follicle (F). There is a presence of autophagic vesicle (AV). Membrane blebbing 
$(\rightarrow)$ are seen at several places indicating cell-cell interaction (Figure 6).

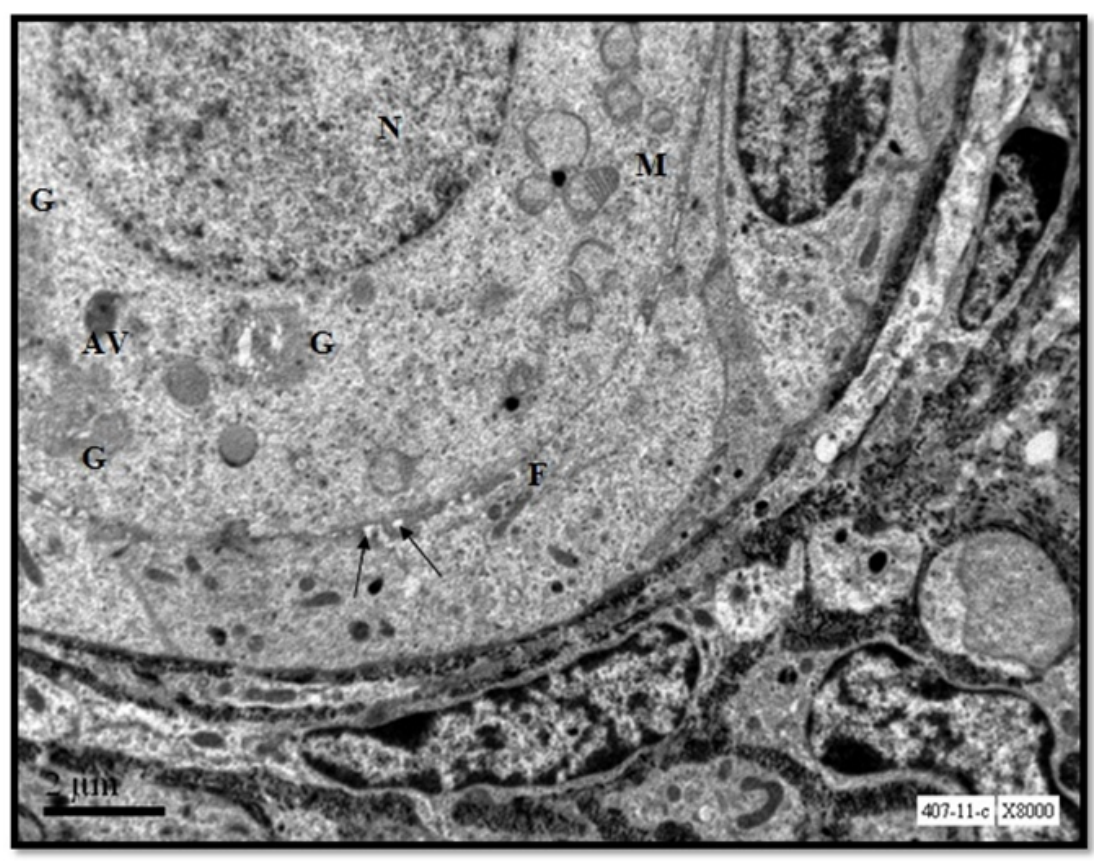

Fig 6. $\mathrm{EM}$ of rat ovary treated with fluoxetine $10 \mathrm{mg} / \mathrm{kg}$ with distinct mitochondria $(\mathrm{M})$ and nucleus $(\mathrm{N})$

Group IV: EM of rat ovary treated with fluoxetine $20 \mathrm{mg} / \mathrm{kg}$ shows ovarian follicle completely degenerated with fibroid encompassing the follicle. Note the invasion of the sterocilia (SC) into the stroma of the follicle. The characteristic structure of ovarian follicle cell is disappearing (Figure 7).

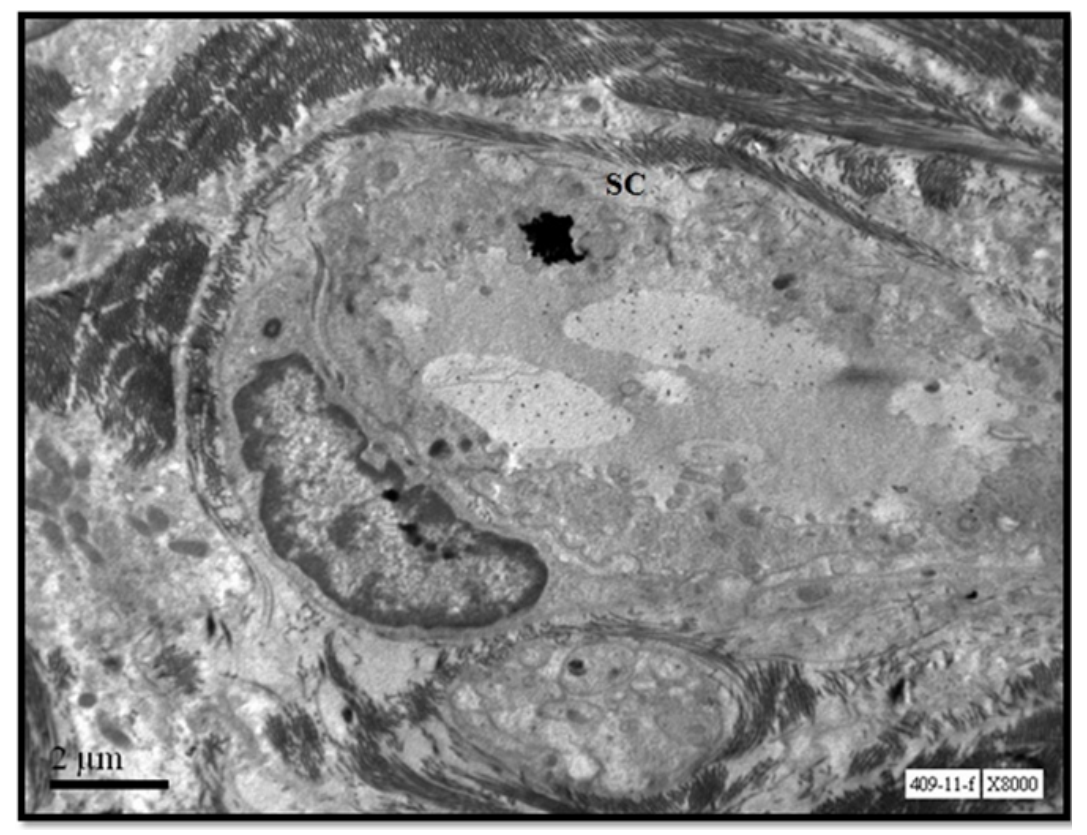

Fig 7. EM of rat ovary treated with fluoxetine $20 \mathrm{mg} / \mathrm{kg}$ shows ovarian follicle completely degenerated

Group IV: EM of rat ovary treated with fluoxetine $20 \mathrm{mg} / \mathrm{kg}$ with inconspicuous nucleus (N). Several hydrated mitochondria $(\mathrm{M})$ and dense bodies $(\rightarrow)$ are also seen. Observe the myelin fibres (MF) (Figure 8). 


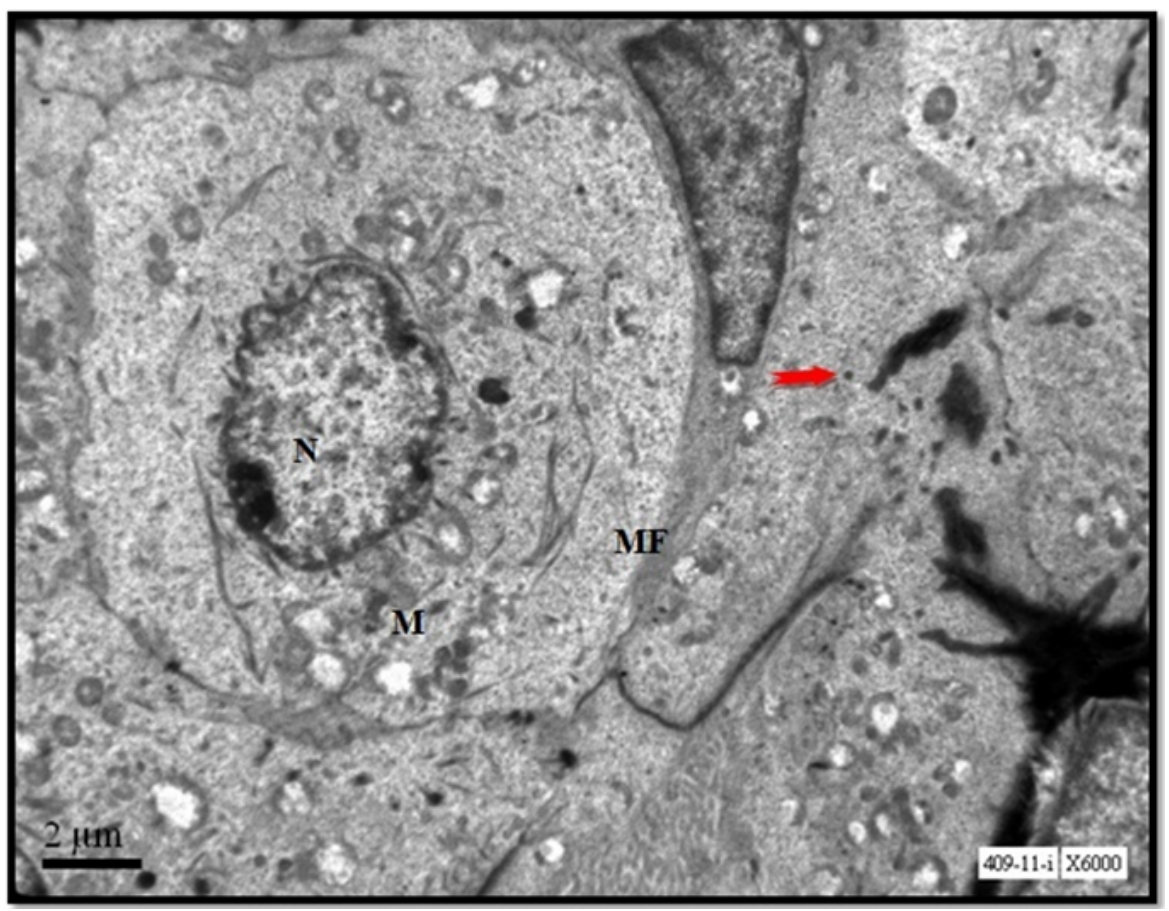

Fig 8. EM of rat ovary treated with fluoxetine $20 \mathrm{mg} / \mathrm{kg}$ with inconspicuous nucleus $(\mathrm{N})$.

\section{Discussion}

The amount of serum estradiol and progesterone in group II is less compared to the control, suggesting a decline in the female hormones during the depression. Earlier researches support this observation and a decrease in estrogen levels is found to have an impact on mood and mental status by its effects on estrogen receptor (ER) $\beta^{(27,28)}$. On treatment with fluoxetine at a dose of $10 \mathrm{mg} / \mathrm{kg}$, there has been an increase in hormone levels, suggestive of a recovery. However, when the treatment dose is increased to $20 \mathrm{mg} / \mathrm{kg}$, there is a decline in the hormone level. This indicates the dysfunctioning and the impairment of the ovaries at a fluoxetine dose of $20 \mathrm{mg} / \mathrm{kg}$. Studies reveal that chronic fluoxetine treatments suppress the circulating estrogen ${ }^{(29)}$. Research work on female goldfish (Carassius auratus) also reported that fluoxetine significantly reduced the expression of (ER) $\beta 1$ $\mathrm{mRNA}^{(30)}$. Fluoxetine's effects to disrupt the female sexual responses and may involve its effects on progesterone in the midbrain VTA (ventral tegmental area) ${ }^{(31)}$. Chronic fluoxetine treatment $(5 \mathrm{mg} / \mathrm{kg} /$ day) completely blocked the increased secretion of corticosterone and progesterone in response to the acute fluoxetine challenge ${ }^{(32)}$.

The variations in the ovarian hormones may be attributed to the structural degeneration of the ovaries as is observed by EM studies. The electron micrographs of rat ovaries in the control group I depicted the normal appearance of stromal cells. A distinct graafian follicle and ovarian follicle under developmental stages were seen in the ovum. The presence of an active Golgi complex, the nucleus with the eccentric nucleolus, intact mitochondria with distinct cristae and a dense matrix indicates a normal condition of the ovary. Animals in depressed group II show a distinct nucleus with the nucleolus in the follicle. However, there are hydrated and ballooned mitochondria with loss of cristae and also the number of mitochondria is more indicating higher synthesis of ATP. Thus, it can be derived that there are more energy requirements in states of depression. There is also the heavy accumulation of polyribosomes indicating heavy protein synthesis. Animals undergoing treatment in group-III with $10 \mathrm{mg} / \mathrm{kg}$ fluoxetine shows a distinct nucleus. Primary ovarian follicle undergoing degeneration and several hydrated mitochondria with loss of cristae are also observed. The presence of autophagic vesicle and membrane blebbing is indicative of some degenerative changes in the structure.

Female rats undergoing treatment with a dose of fluoxetine at $20 \mathrm{mg} / \mathrm{kg}$ in group-IV show an inconspicuous nucleus and the appearance of several hydrated mitochondria which indicates damage to the organelle. There are reports of fluoxetine inducing a change in the mitochondrial membrane permeability and formation of reactive oxygen species, leading to cell death or apoptosis ${ }^{(33)}$. There is an invasion of the sterocilia into the stroma of the follicle which destroys the characteristic structure of the ovarian follicle. An increase in the number of atretic follicles, oocyte fragmentation, damaged zona pellucidas have been 
reported in animals treated with fluoxetine ${ }^{(34,35)}$. A dose of flouxetine drug has also been found to reduce the number of graafian and prenatal follicles and corpus luteum, which reflect trauma in ovarian tissue ${ }^{(36)}$.

\section{Conclusion}

Fluoxetine treatment at a dose of $20 \mathrm{mg} / \mathrm{kg}$ results in degenerative changes in the ovaries of female rats by inducing a fibroid condition as is evident from the electron micrographs. The significant decrease in the levels of estradiol and progesterone reveals the dysfunctioning of the ovaries at $20 \mathrm{mg} / \mathrm{kg}$ and not at $10 \mathrm{mg} / \mathrm{kg}$ fluoxetine treatment.

The study concludes that fluoxetine having a wider therapeutic index for major depressive disorders causes impairment to the ovarian tissues in female rats. Fluoxetine therapy given to human females may as well exhibit a similar effect on the ovaries. Further research is essential to understand the effects of fluoxetine on gametogenesis in the female ovary.

\section{References}

1) Fuller RW, Wong DT, Robertson DW. Fluoxetine, a selective inhibitor of serotonin uptake. Medicinal Research Reviews. 1991;11:17-34. Available from: https://dx.doi.org/10.1002/med.2610110103.

2) Healy D. The antidepressant era. and others, editor;Harvard University Press. 1997. Available from: https://books.google.com/books?hl=en\&lr=\&id= 6lpHd_P4VOsC\&oi=fnd\&pg=PR9\&dq=The+Antidepressant+Era\&ots=86GSOo-gOQ\&sig=u3IOASQNCL5o5jdRDIzcqtWRyu0.

3) Preston J, Neal JHO, Talaga MC. Handbook of clinical psychopharmacology for therapists. and others, editor;New Harbinger Publications. 2010. Available from: https://cutt.ly/okW16gS.

4) Schatzeberg AF, Cole JO, Debattista C. History of antidepressant. Manual of Clinical Psychopharmacology. and others, editor. 2007. Available from: https://cutt.ly/6kW0i5k.

5) Peselow ED, Sanfilipo MP, Difiglia C, Fieve RR. Melancholic/endogenous depression and response to somatic treatment and placebo . The American journal of psychiatry. 1992;149(10):1324-1334. Available from: https://psycnet.apa.org/record/1993-10712-001.

6) Burke MJ, Preskorn SH. Short-term treatment of mood disorders with standard antidepressants. In: FE FEB, Kupfer DJ, editors. Psychopharmacology: the fourth generation of progress. New York. Raven Press. 1995;p. 1053-1065. Available from: https://onlinelibrary.wiley.com/doi/abs/10.1002/ddr. 430350314.

7) Pohland RC, Byrd TK, Hamilton M, Koons JR. Placental transfer and fetal distribution of fluoxetine in the rat. Toxicology and Applied Pharmacology. 1989;98:198-205. Available from: https://dx.doi.org/10.1016/0041-008x(89)90225-1.

8) Velasco A, Alamo C, Hervás J, Carvajal A. Effects of fluoxetine hydrochloride and fluvoxamine maleate on different preparations of isolated guinea pig and rat organ tissues. General Pharmacology: The Vascular System. 1997;28:509-512. Available from: https://dx.doi.org/10.1016/s0306-3623(96)00274-1.

9) Matuszcyk J. The Selective Serotonin Reuptake Inhibitor Fluoxetine Reduces Sexual Motivation in Male Rats. Pharmacology Biochemistry and Behavior. 1998;60(2):527-532. Available from: https://dx.doi.org/10.1016/s0091-3057(98)00010-0.

10) Ho HP, Olsson M, Pharm M, Westberg L, Melke J, Eriksson E. The serotonin reuptake inhibitor fluoxetine reduces sex steroid-related aggression in female rats: an animal model of premenstrual irritability? Neuropsychopharmacology. 2001;24(5):502-510. Available from: https://www.nature.com/articles/ 1395627.

11) Parr EL. Histological Examination of the Rat Ovarian Follicle Wall Prior to Ovulation. Biology of Reproduction. 1974;11(5):483-503. Available from: https://dx.doi.org/10.1095/biolreprod11.5.483.

12) Lee MT, Anderson E, Lee GY. Changes in ovarian morphology and serum hormones in the rat after treatment with dehydroepiandrosterone. The Anatomical Record. 1991;231:185-192. Available from: https://dx.doi.org/10.1002/ar.1092310206.

13) Jelodar GH, Karami E. Effect of hydroalcoholic extract of vitex agnus-castus fruit on ovarian histology in rat with induced Polycystic Ovary Syndrome (PCOS). Journal of BABOL University of Medical Sciences. 2013;15(3):96-102. Available from: http://jbums.org/article-1-4416-en.html.

14) Merk FB, Botticelli CR, Albright JT. An Intercellular Response to Estrogen by Granulosa Cells in the Rat Ovary; An Electron Microscope Study*. Endocrinology. 1972;90(4):992-1007. Available from: https://dx.doi.org/10.1210/endo-90-4-992.

15) Devine PJ, Payne CM, McCuskey MK, Hoyer PB. Ultrastructural Evaluation of Oocytes During Atresia in Rat Ovarian Follicles1. Biology of Reproduction. 2000;63(5):1245-1252. Available from: https://dx.doi.org/10.1095/biolreprod63.5.1245.

16) Shors T. Estrogen-mediated effects on depression and memory formation in females. Journal of Affective Disorders. 2003;74(1):85-96. Available from: https://dx.doi.org/10.1016/s0165-0327(02)00428-7.

17) Finnell JE, Muniz BL, Padi AR, Lombard CM, Moffitt CM, Wood CS, et al. Essential Role of Ovarian Hormones in Susceptibility to the Consequences of Witnessing Social Defeat in Female Rats. Biological Psychiatry. 2018;84:372-382. Available from: https://dx.doi.org/10.1016/j.biopsych.2018.01.013.

18) Horst GJT, Wichmann R, Gerrits M, Westenbroek C, Lin Y. Sex differences in stress responses: Focus on ovarian hormones. Physiology \& Behavior. 2009;97(2):239-249. Available from: https://dx.doi.org/10.1016/j.physbeh.2009.02.036.

19) Li LH, Wang ZC, Yu J, Zhang YQ. Ovariectomy results in variable changes in nociception, mood and depression in adult female rats. PloS one. 2014;9(4). Available from: https://journals.plos.org/plosone/article?id=10.1371/journal.pone.0094312.

20) Frye CA, Wawrzycki J. Effect of prenatal stress and gonadal hormone condition on depressive behaviors of female and male rats. Hormones and behavior. 20031;44(4):319-326. Available from: https://www.sciencedirect.com/science/article/pii/S0018506X03001594.

21) Overstreet DH. Modeling depression in animal models. Psychiatric Disorders. 2012;p. 125-144. Available from: https://link.springer.com/protocol/10. 1007/978-1-61779-458-2_7.

22) Bant WP. Antihypertensive drugs and depression: a reappraisal. Psychological Medicine. 1978;8:275-283. Available from: https://dx.doi.org/10.1017/ s003329170001432x.

23) Bein HJ. Prejudices in Pharmacology and Pharmacotherapy: Reserpine as a Model for Experimental Research in Depression. Pharmacopsychiatry. 1978;11(06):289-293. Available from: https://dx.doi.org/10.1055/s-0028-1094588.

24) Yamashita K, Kitayama I, Hamanaka K, Nomura J. Effect of reserpine on 3-methoxy-4-hydroxyphenylethyleneglycol and 3,4-dihydroxyphenylacetic acid in the hippocampus of depression-model rats: An in vivo microdialysis study. Brain Research. 1998;785:10-17. Available from: https://dx.doi.org/10.1016/ 
s0006-8993(97)01339-5.

25) Minor TR, Huang Q, Foley EA. Cytokine-purine interactions in behavioral depression in rats. Integrative Physiological \& Behavioral Science. 2003;38(3):189-202. Available from: https://dx.doi.org/10.1007/bf02688853.

26) Unnikrishnan G, Shivabalan R, Lillian J. Sub-acute toxicity of fluoxetine hydrochloride on fertility of male wistar rats. J Herb Med Toxicol. 2009;3:23-30.

27) Biver F, Wikler D, Lotstra F, Damhaut P, Goldman S, Mendlewicz J. Serotonin 5-HT2 receptor imaging in major depression: focal changes in orbito-insular cortex. British Journal of Psychiatry. 1997;171(5):444-448. Available from: https://dx.doi.org/10.1192/bjp.171.5.444.

28) Rocha BA, Fleischer R, Schaeffer JM, Rohrer SP, Hickey GJ. 17 $\beta$-Estradiol-induced antidepressant-like effect in the Forced Swim Test is absent in estrogen receptor- $\beta$ knockout (BERKO) mice. Psychopharmacology. 2005;179(3):637-643. Available from: https://dx.doi.org/10.1007/s00213-004-2078-1.

29) Taylor GT, Farr S, Klinga K, Weiss J. Chronic fluoxetine suppresses circulating estrogen and the enhanced spatial learning of estrogentreated ovariectomized rats. Psychoneuroendocrinology. 2004;29(10):1241-1250. Available from: https://www.sciencedirect.com/science/article/pii/ S0306453004000319.

30) Mennigen JA, Martyniuk CJ, Crump K, Xiong H, Zhao E, Popesku J, et al. Effects of fluoxetine on the reproductive axis of female goldfish (Carassius auratus). Physiological Genomics. 2008;35:273-282. Available from: https://dx.doi.org/10.1152/physiolgenomics.90263.2008.

31) Frye CA, Rhodes ME. Fluoxetine-Induced Decrements in Sexual Responses of Female Rats and Hamsters Are Reversed by $3 \alpha, 5 \alpha$-THP. The Journal of Sexual Medicine. 2010;7:2670-2680. Available from: https://dx.doi.org/10.1111/j.1743-6109.2010.01814.x.

32) Duncan GE, Knapp DJ, Carson SW, Breese GR. Differential effects of chronic antidepressant treatment on swim stress-and fluoxetine-induced secretion of corticosterone and progesterone. Journal of Pharmacology and Experimental Therapeutics. 1998;285(2):579-587. Available from: http://jpet.aspetjournals. org/content/285/2/579.short.

33) Lee CS, Kim YJ, Jang ER, Kim W, Myung SC. Fluoxetine Induces Apoptosis in Ovarian Carcinoma Cell Line OVCAR-3 Through Reactive Oxygen SpeciesDependent Activation of Nuclear Factor- $\kappa$ B. Basic \& clinical pharmacology \& toxicology. 2010;106(6):446-453. Available from: https://onlinelibrary.wiley. $\mathrm{com} / \mathrm{doi} / \mathrm{abs} / 10.1111 / \mathrm{j} .1742-7843.2009 .00509 . x$.

34) Romero-Reyes J, Cárdenas M, Damián-Matsumura P, Domínguez R, Ayala ME. Inhibition of serotonin reuptake in the prepubertal rat ovary by fluoxetine and effects on ovarian functions. Reproductive Toxicology. 2016;59:80-88. Available from: https://dx.doi.org/10.1016/j.reprotox.2015.12.006.

35) Mansoriyan M, Torabzadehkhorasani P, Ramezani M. Effect of Fluoxetine on Ovarian and Oviduct Tissue in Female Mature Balb/C Mice. J Adv Med Biomed Res. 2018;26(116):100-110. Available from: http://repository.zums.ac.ir/id/eprint/3333/.

36) Mohammad P, Hossein KJ. The investigation into the effect of flouxetine on quantity of ovarian follicles in adult female rats. Biomedical \& Pharmacology Journal. 2014;7(1):375-378. Available from: https://cutt.ly/VkW9UMI. 